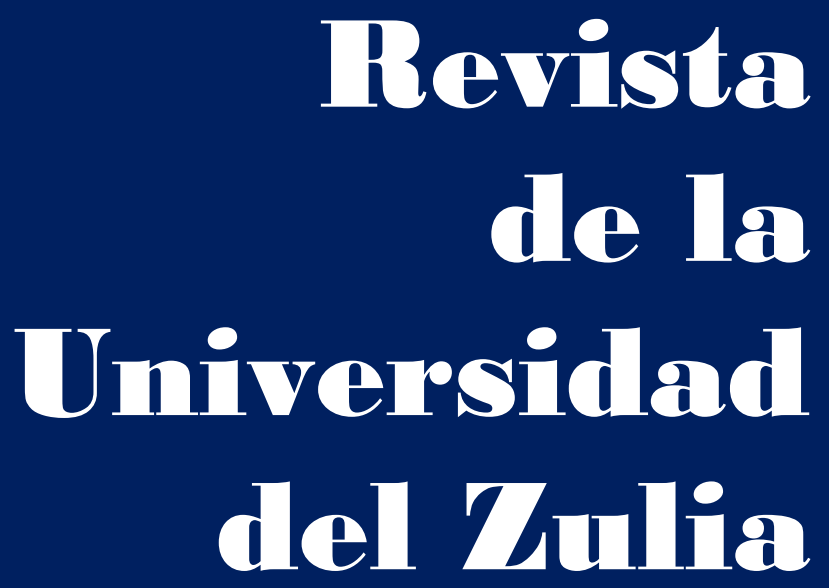

Fundada en 1947

por el Dr. Jesús Enrique Lossada

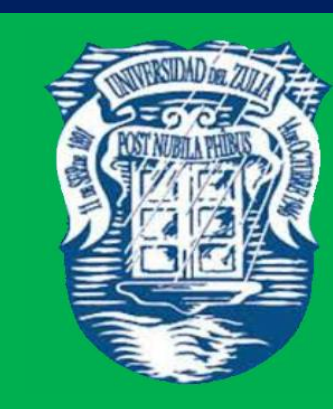

Ciencias del

Agrad,

Ingemiería

y Tecinología

\section{Aกัต 13 No $\mathbf{3 6}$} Enero - Abril 2022

Tercera Épaca

Maracailbo-Venezuela 
REVISTA DE LA UNIVERSIDAD DEL ZULIA. $3^{a}$ época. Año $13 \mathrm{~N}^{\circ}$ 36, 2022

Golovin Artem Alekseevich et al. /// Results of the Russian State policy in the field of increasing ... 93-113

DOI: http://dx.doi.org/10.46925//rdluz.36.07

\title{
Results of the Russian State policy in the field of increasing food availability
}

\author{
Golovin Artem Alekseevich * \\ Kalinicheva Elena Yurievna ** \\ Reprintseva Elena Vasilievna *** \\ Nozdracheva Elena Nikolaevna **** \\ Zyukin Danil Alekseevich *****
}

\begin{abstract}
The purpose of the study was to assess the impact of the Russian state policy on agricultural production and food availability in the context of food security. Using methodological tools, statistical data about production, consumption and prices of food products were processed. In the course of the work, it was determined that the agriculture of Russia shows a fairly high rate of development. The positive aspect is that this growth is provided mainly by intensive factors. The sale prices of agricultural producers show high growth rates, which negatively affects the availability of food for the country's population. In general, Russia's agriculture, under the conditions of the food embargo and economic sanctions, shows good results. It is proposed that the State changes the emphasis from state support from grain and pig farming to growing vegetables, growing fruits, and raising livestock, including milk products. Increasing support to these areas will increase the volume of agricultural production of high value-added goods, which will have a positive impact on the development of rural areas and the diversification of exports. At the same time, state support should be left in the direction of the production of class 1 and 2 cereals and the processing of pork.
\end{abstract}

KEY WORDS: production; supply-side economics; public administration; macroeconomics; agricultural industries; economic policy, Russia.

*Candidate of sciences of economic, Associate professor of the department «Customs and world economy», Southwestern state university. ORCID: https://orcid.org/0000-0001-6688-3561. E-mail: cool.golovin2011@yandex.ru

**Doctor of sciences of economic, Associate professor in economics, Professor of the department «Accounting and statistics» Oryol state agrarian university named after N.V. Parakhin. ORCID: https://orcid.org/00000002-9310-3281, E-mail: len-kalinichev@mail.ru

${ }^{* * *}$ Candidate of sciences of pharmaceuticals, Associate professor in economics, Associate professor of department «Economics and management» Kursk state medical university. ORCID: https://orcid.org/00000003-0655-6360. E-mail: elena.reprin@yandex.ru

****Candidate of sciences of economic, Associate professor in economics, Associate professor of the department «Economics and accounting» Kursk state university. ORCID: https://orcid.org/0000-0002-07839453. E-mail: nen.kgu@mail.ru

${ }^{* * * * *}$ Candidate of sciences of economic, Senior researcher at the research center, Kursk state agricultural academy named after I.I. Ivanov. ORCID: https://orcid.org/0000-0001-8118-2907. E-mail: nightingale46@rambler.ru 


\section{Resultados de la política del Estado ruso en el ámbito del aumento de la disponibilidad de alimentos}

\section{RESUMEN}

El propósito del estudio consistió en evaluar el impacto de la política del Estado ruso sobre la producción agrícola y la disponibilidad de alimentos en el contexto de la seguridad alimentaria. Utilizando herramientas metodológicas, se procesaron datos estadísticos sobre producción, consumo y precios de productos alimenticios. En el curso del trabajo, se determinó que la agricultura de Rusia muestra una tasa de desarrollo bastante alta. El aspecto positivo es que este crecimiento es proporcionado principalmente por factores intensivos. Los precios de venta de los productores agrícolas muestran altas tasas de crecimiento, lo que afecta negativamente la disponibilidad de alimentos para la población del país. En general, la agricultura de Rusia, bajo las condiciones del embargo alimentario y las sanciones económicas, muestra buenos resultados. Se propone que el Estado cambie el énfasis del apoyo estatal de la cría de cereales y la cría de cerdos hacia el cultivo de hortalizas, el cultivo de frutas y la cría de ganado, incluidos los productos lácteos. Aumentar el apoyo a estas áreas incrementará el volumen de producción agrícola de bienes de alto valor agregado, lo que tendrá un impacto positivo en el desarrollo de las áreas rurales y la diversificación de las exportaciones. Al mismo tiempo, el apoyo estatal debe dejarse en la dirección de la producción de cereales de clase 1 y 2 y el procesamiento de carne de cerdo.

PALABRAS CLAVE: producción; economía del lado de la oferta; administración pública; macroeconomía; industrias agrícolas; política económica; Rusia.

\section{Introduction}

The struggle to keep Ukraine in Russia's sphere of influence led to the adoption of economic sanctions by the United States, Canada, Australia, and the European Union countries, which had a strong impact on the economic situation in the country. Since the adoption of the sanctions, the World Bank has not approved a single decision on investment in projects within Russia. The supply of high-tech goods was restricted, and the supply of dual-use goods, goods that can be used in both civil and military projects, was completely prohibited. The economic chains between the enterprises of Ukraine and Russia were completely destroyed. Trade turnover between Russia and the countries that have adopted sanctions has dropped significantly. All these factors, as well as the fall in oil prices, have led to significant damage to the country's economy, as well as to the population. 
REVISTA DE LA UNIVERSIDAD DEL ZULIA. $3^{a}$ época. Año $13 \mathrm{~N}^{\circ}$ 36, 2022

Golovin Artem Alekseevich et al. /// Results of the Russian State policy in the field of increasing ... 93-113

DOI: http://dx.doi.org/10.46925//rdluz.36.07

In response, Russia introduced a food embargo in 2014 that was a ban on the supply of food products to the country, the country of origin of which are the countries participating in the sanctions pressure. As a result of the food embargo, a significant market share turned out to be free, the diversification of import supplies in 2014 and even in 2015 was not completely possible to implement, and, therefore, Russian food producers had the opportunity to increase their share in the domestic market. Together with the import ban, the liberation of the market part from competitors, there was an increase in food prices, profitability increased by 5-10 points for some food products. However, an increase of food prices, devaluation of the national currency, and reduction of budget spending on social projects endangered the country's food and economic security.

Food security is determined by the totality of food production and availability. On the one hand, rising prices and embargo stimulated food production, on the other hand, there was a decrease in the availability of food. The components of economic security are reflected in the aspect of the development of labor resources and the sustainability of the functioning of agricultural entities. Without affordable and high-quality food, it is impossible to develop labor resources, as well as to ensure population growth. The low stability of agricultural production entities is manifested in the instability of the conditions of the internal and external environment. The lifting of restrictions on the food embargo may lead to the fact that the investment projects in the agro-industrial complex will lose profitability or become unprofitable. In addition, the devaluation of the national currency and high inflation have determined costs' increase. Prices for seeds, fertilizers, fuels and lubricants, machinery, equipment have increased significantly under the influence of the factors presented above.

Thus, the relevance of the study is determined by the need to assess the impact of the country's state policy on ensuring food and economic security.

The purpose of the study is the need to assess the impact of government policy on agricultural production and food availability in the context of ensuring food security.

Achieving the study purpose required solving the following tasks:

- to analyze changes in the volume of production of food products and raw materials for its production;

- to assess the impact of the extensive factor on the production of food products and raw materials for its production; 
REVISTA DE LA UNIVERSIDAD DEL ZULIA. $3^{a}$ época. Año $13 \mathrm{~N}^{\circ}$ 36, 2022

Golovin Artem Alekseevich et al. /// Results of the Russian State policy in the field of increasing ... 93-113

DOI: http://dx.doi.org/10.46925//rdluz.36.07

- to assess the impact of the intensive factor on the production of food products and raw materials for its production;

- to analyze the prices of agricultural producers;

- to analyze the consumption of basic food products by the population of the country.

Public-private relations regarding the production, processing and consumption of food products are identified as the object of the study. The subject of the study is the country's food security.

The hypothesis of the study is the scientific assumption that the Russian food embargo did not sufficiently ensure the development of agriculture, which led to an increase in food prices and negatively affected the volume of its consumption by the population.

\section{Theoretical basis}

The theoretical basis of the study is formed on the basis of scientific works of Russian and foreign scientists, published in leading peer-reviewed scientific journals, presented in monographs, educational publications, dissertations, collections of conference proceedings for the issues under study.

The issues of state regulation of agricultural production in order to ensure food security are widely considered in the works of such scientists as C.G. Brown, S.R. Johnson, J. Vik, X.D. Guo, P. Lung, J.L. Sui, R.P. Zhang, C. Wang, R. Beluhova-Uzunova, K. Hristov, M. Shishkova, D.J. Pannell, R. Claassen, O. Ecker, P.L. Hatzenbuehler, E. Calegari, E. Fabrizi, G. Guastella, F. Timpano.

S.R. Johnson in the study "How nutrition policy affects food and agricultural policy" identifies the importance of food production and availability for labor resources development, which corresponds to one of the areas of economic security (Johnson, 1994). In his work, he does not distinguish between agriculture and food consumption, he considers these areas as a complex. He also pays great attention to the quality of food products. S.R. Johnson believes that modern food and agricultural policy should ensure the quality of the produced food.

In the work "The agricultural policy trilemma: On the wicked nature of agricultural policy making. Land use policy" J. Vik considered agricultural policy as a complex, multidimensional activity based on mutually exclusive goals (Vik, 2020). Using the example of agriculture in Norway, he conducted a study of the trilemma of agricultural policy. In the 
REVISTA DE LA UNIVERSIDAD DEL ZULIA. $3^{a}$ época. Año $13 \mathrm{~N}^{\circ}$ 36, 2022

Golovin Artem Alekseevich et al. /// Results of the Russian State policy in the field of increasing ... 93-113

DOI: http://dx.doi.org/10.46925//rdluz.36.07

course of his work, he identified three tasks of agricultural policy, shifting the focus to solving only one of them can lead to disastrous consequences.

X.D. Guo, P. Lung, J.L. Sui, R.P. Zhang, and C. Wang in the work "Agricultural Support Policies and China's Cyclical Evolutionary Path of Agricultural Economic Growth" analyzed the development of agricultural production in China, which allowed them to distinguish three production cycles (Guo et al., 2021). An important achievement was the assessment of the probability of changing production cycles in the country's agricultural sector. The work carried out made it possible to determine that active government support has ensured sustainable growth dynamics. However, China's agriculture development will lead to the decrease of growth rates that is natural and determined by the established scale of the industry.

R. Beluhova-Uzunova, K. Hristov and M. Shishkova in the published study "The common agricultural policy post 2020 - farmers' perception and policy implication" analyze the state of agriculture, and also determine the place of the state in its development (Beluhova-Uzunova et al., 2020). The basis of their study was the analysis of 74 agricultural producers, according to the results of which it became clear that state support is more effectively provided for large farms, and small enterprises are in less advantageous conditions. The authors give data that government support is mainly directed to support animal husbandry and cultivation of crops with high added value. In conclusion of the study, it was determined that support should be implemented in a targeted way, and not in a general one.

Targeted support for agricultural producers was also supported by C.G. Brown. In his work "Removing redundant regulation in the reform of agricultural policies - the case of the common agricultural policy of the EC", he revealed that, despite the development of government support mechanisms, administrative and bureaucratic barriers to its receipt and use increase (Brown, 1994). C.G. Brown believes that removing administrative and bureaucratic barriers, as well as unnecessary control, will give a new impetus to the development of agriculture in Europe.

D.J. Pannell and R. Claassen in their work "The Roles of Adoption and Behavior Change in Agricultural Policy" focused on the interaction of agriculture and the environment (Pannell, Claassen, 2020). The authors consider state support of agriculture as a stimulating 
REVISTA DE LA UNIVERSIDAD DEL ZULIA. $3^{a}$ época. Año $13 \mathrm{~N}^{\circ}$ 36, 2022

Golovin Artem Alekseevich et al. /// Results of the Russian State policy in the field of increasing ... 93-113

DOI: http://dx.doi.org/10.46925//rdluz.36.07

tool for the modernization of production, the use of new ways of conducting and organizing the economy that meets the modern environmental agenda.

O. Ecker and P.L. Hatzenbuehler in the article "Food consumption-production response to agricultural policy and macroeconomic change in Nigeria" assess the impact of state agricultural and macroeconomic policies on food production and consumption (Ecker, Hatzenbuehler, 2021). Nigeria, like Russia, is a developing resource-oriented country. As in Russia, the country has an unstable national currency. Nigeria is heavily dependent on export foreign exchange earnings and imported labor. The negative macroeconomic phenomena in Nigeria have led to the fact that households increased food production for their own consumption, and large companies for export. However, rational state policy has made it possible to reduce the negative impact of crisis phenomena in the national economy.

E. Calegari, E. Fabrizi, G. Guastella and F. Timpano contributed to the theory and practice of state regulation of food production. In the work "EU regional convergence in the agricultural sector: Are there synergies between agricultural and regional policies?" the authors analyze the common agricultural policy of the EU countries (Calegari et al., 2021). The authors argue that agricultural policy has recently acquired significant regionalism, which contradicts the unity of Europe. In the course of the study, the authors concluded that in the EU countries with a low level of agricultural development, a unified agricultural policy leads to negative consequences, and in agrarian developed countries, on the contrary.

Among Russian agricultural scientists, such scientists as E.B. Razuvaeva, B.A. Voronin, I.P. Chupina, Ya.V. Voronina, V.V. Drokin, A.S. Unravel, N.V. Rodnina and others made a significant contribution to the development of food economics, but the prominent agricultural economist, academician of the Russian Academy of Sciences A.I. Altukhov deserves special attention.

The fundamental work of A.I. Altukhov "The food security paradigm of Russia" (Altukhov, 2019) can be considered an anthology of food security and regulation of agricultural production. This work covers the methodology of assessment, risks, threats, challenges, government regulation, as well as territorial aspects of food security.

The sphere of scientific interests of E.B. Razuvaeva is economic security and the impact of food security on it. In his work "Food security as an important component of ensuring the economic security of the country" the author substantiates the need to provide 
REVISTA DE LA UNIVERSIDAD DEL ZULIA. $3^{a}$ época. Año $13 \mathrm{~N}^{\circ}$ 36, 2022

Golovin Artem Alekseevich et al. /// Results of the Russian State policy in the field of increasing ... 93-113

DOI: http://dx.doi.org/10.46925//rdluz.36.07

food for the population from the perspective of the policy of economic security formation (Razuvaeva, 2020).

The issues of agroecology, agricultural land management, food security are reflected in the works of B.A. Voronin. So, in the work "Conditions for the development of the market for organic products in Russia as a factor of compliance with food security", the importance of organic production for ensuring food security is determined, and the Russian food market is analyzed (Voronin et al., 2020).

A significant contribution to the study of agri-food systems was made by V.V. Drokin. In his works, the scientist examines the territorial features of agricultural production, its competitiveness, government regulation, as well as food security itself. In the work "On the food security of the rural population of the regions of Russia" the authors examine the level of food security of the rural population of Russia, the population, which itself is a source of food. At the end of the study, V.V. Drokin and A.S. Zhuravlev came to the disappointing conclusion that the quality of nutrition of the rural population is inferior to the urban one, both in quantitative terms and in terms of the balance of nutrients (Drokin, Zhuravlev, 2020).

Another agricultural scientist who made a significant contribution to the development of scientific provisions of food security is N.V. Rodnina. It is worth noting her work "Food Security Doctrine: Regional Aspect", in which the author examines the regional features of ensuring food security (Rodnina, 2021). N.V. Rodnina in her works tries to cover all the factors that form food security, from natural conditions to human resources and fixed assets.

Despite significant developments in the field of regulation of agricultural production, a fairly large number of issues remain debatable, namely, a rational state policy for ensuring food security, the impact of state policy on the food availability and agricultural production volumes, and others.

\section{Methodology}

The study materials were formed on the basis of statistical data from the Federal State Statistics Service, the Ministry of Agriculture of the Russian Federation, electronic library systems: "Scientific Electronic Library" and "National Electronic Library", as well as modern professional databases: "Electronic library of dissertations of the Russian State Library "," Web of Science "and" Scopus ". 
REVISTA DE LA UNIVERSIDAD DEL ZULIA. $3^{a}$ época. Año $13 \mathrm{~N}^{\circ}$ 36, 2022

Golovin Artem Alekseevich et al. /// Results of the Russian State policy in the field of increasing ... 93-113

DOI: http://dx.doi.org/10.46925//rdluz.36.07

The methodological study tools included such general scientific methods as analysis, synthesis, horizontal analysis, the method of graphic interpretation of statistical information, the empirical method and other scientific methods that solved the study objectives.

Within the framework of the study, the purpose, objectives, and hypothesis of the study were determined. To achieve the stated purposes, it is necessary to determine the volume of agricultural production in Russia and its change under the influence of extensive and intensive factors. Extensive factors in the framework of this study should be understood as a change in the area of crops and perennial plantings for the crop industry and change in the number of farm animals and number of bee colonies for animal husbandry. The intensive factor is determined by the efforts of agricultural producers to obtain better results. In crop production, these efforts are related to investments in seeds, assortments, mineral fertilizers, plant protection products, equipment, new forms of production organization, etc. In animal husbandry, these efforts are manifested in the acquisition of more productive breeds of animals, construction and re-equipment of farms, development and improvement of feed base, acquisition of veterinary drugs and feed additives, etc. The simplest indicators of the impact of intensive factor on food production are yield of agricultural crops and productivity of farm animals.

The availability of food is influenced by its price and income of the population. To assess food availability, data on the average annual food consumption can be used. This study uses producer prices, i.e., prices at which agricultural enterprises sold food products and raw materials for their production. This choice is justified by the purpose of the study, namely the activities of commodity producers and consumers of food. Margins, logistics costs and other selling costs are not related to food production. The exception was the prices for granulated sugar and honey, as there were no data on the sale prices of sugar beets for processing plants in open sources. For honey, the situation is different. Most of the product is produced by the population, therefore, sales prices are not recorded.

The interval of 2013-2018 was defined as the study period. The comparison of 2018 was carried out since 2014. The choice of interval is determined by the need to investigate economic processes before the outbreak of the pandemic, which had a negative impact on both the economy and population. Comparison of 2018 with 2014 is carried out in order to see the changes taking place in the conditions of economic sanctions and food embargo. 
REVISTA DE LA UNIVERSIDAD DEL ZULIA. $3^{a}$ época. Año $13 \mathrm{~N}^{\circ}$ 36, 2022

Golovin Artem Alekseevich et al. /// Results of the Russian State policy in the field of increasing ... 93-113

DOI: http://dx.doi.org/10.46925//rdluz.36.07

\section{Results}

Wheat is the main agricultural crop of the country. Its high importance is determined by food and feed value, as well as significant export potential. According to table l, it can be seen that wheat production in Russia for 2013-2018. showed an increase of 20.8\%. Since the embargo, the volume of production has increased by 12.4 million tons. Wheat exports take central place in the export of food products.

The situation is multidirectional for the rest of the grain and leguminous crops. Corn production for grain showed a weak 0.9\% growth. Buckwheat production increased 1.4 times, and leguminous production increased 1.5 times. Buckwheat production showed high volatility, so in 2014 the volume of production amounted to only 662 thousand tons, and reached 1.5 million tons by 2017, then in 2018 it decreased to 932 thousand tons. The production of rye, triticale, barley, oats, millet, and rice showed a decrease from 10 to 56\%. The smallest decrease in production volumes is observed for rice $-1 \%$ (Table 1 ).

Industrial crops show an increase in production volumes. During the study period, the production of sugar beets increased by 8.6 million tons, soybeans by 1.7 times, and sunflower seeds by 1.5 times. In 2014 , compared to 2013 , the production of all industrial crops, except for soybeans, decreased.

The production of vegetable and melon crops shows weak growth dynamics, except for potatoes, the volume of production of which decreased by $7.8 \%$. The production of vegetables increased by $7 \%$, or only by 0.9 million tons, and food melons by $33.3 \%$, which corresponds to an increase of 500 thousand tons.

The production of fruit and berry products shows a positive growth trend. For 20132018 the gross harvest of fruits and berries increased by 557 thousand tons, which corresponds to an increase of $20 \%$, and grapes by 58 thousand tons, or $10.2 \%$. In general, the production of fruit and berry products develop at a fairly high rate, however, they are insufficient to cover the volumes of products prohibited for import from Europe.

Livestock production shows an increase in pigs, sheep, goats, poultry and milk, and a decrease in cattle and honey. The highest growth rates were shown by the production of pig meat $(26.3 \%)$, and the smallest was milk production $(2 \%)$. In general, it can be noted that the growth rate of milk production is insufficient to cover the country's needs, and the same can be noted for cattle meat and honey. 
REVISTA DE LA UNIVERSIDAD DEL ZULIA. $3^{a}$ época. Año $13 \mathrm{~N}^{\circ}$ 36, 2022

Golovin Artem Alekseevich et al. /// Results of the Russian State policy in the field of increasing ... 93-113

DOI: http://dx.doi.org/10.46925//rdluz.36.07

As noted earlier, the cultivated area and livestock population were chosen as indicators of the extensive factor. Therefore, based on the data in Table 2, it is necessary to analyze the change in cultivated area / livestock, which will determine what caused the increase or decrease in production.

Table 1 - Production volumes of food products and raw materials for its production in Russia for 2013-2018

\begin{tabular}{|c|c|c|c|c|c|c|c|c|c|}
\hline Culture & 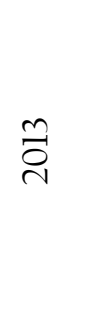 & $\stackrel{+}{\stackrel{\dagger}{\sigma}}$ & $\stackrel{n}{\stackrel{n}{2}}$ & 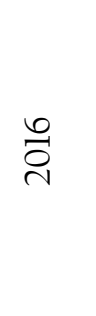 & 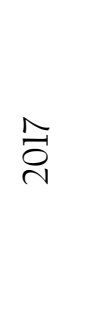 & $\stackrel{\infty}{\stackrel{\infty}{\sim}}$ & 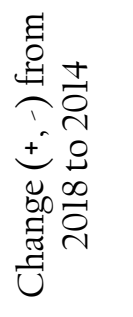 & 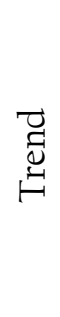 & 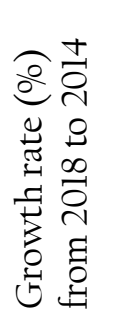 \\
\hline \multicolumn{10}{|c|}{ Crop production, million tons } \\
\hline Wheat & 52.1 & 59.7 & 61.8 & 73.3 & 86 & 72.1 & 12.4 & $\mathbf{A}$ & 120.8 \\
\hline Rye (winter) & 3.4 & 3.3 & 2.1 & 2.5 & 2.5 & 1.9 & -1.4 & $\nabla$ & 57.6 \\
\hline Corn for grain & 11.6 & 11.3 & 13.1 & 15.3 & 13.2 & 11.4 & 0.1 & $\Delta$ & 100.9 \\
\hline Triticale & 0.6 & 0.7 & 0.6 & 0.6 & 0.5 & 0.4 & -0.3 & $\nabla$ & 57.1 \\
\hline Barley & 15.4 & 20.4 & 17.5 & 18 & 20.6 & 17 & -3.4 & $\bar{\nabla}$ & 83.3 \\
\hline Oats & 4.9 & 5.3 & 4.5 & 4.8 & 5.5 & 4.7 & -0.6 & $\nabla$ & 88.7 \\
\hline Millet, thousand tons & 419 & 493 & 572 & 629 & 316 & 217 & -276 & 7 & 44.0 \\
\hline Buckwheat, thousand tons & 834 & 662 & 861 & 1187 & 1525 & 932 & 270 & $\Delta$ & 140.8 \\
\hline Rice, thousand tons & 935 & 1049 & 1110 & 1081 & 987 & 1038 & -11 & $\nabla$ & 99.0 \\
\hline Legumes & 2 & 2.2 & 2.4 & 2.9 & 4.3 & 3.4 & 1.2 & $\mathbf{A}$ & 154.5 \\
\hline Sugar beet & 39.3 & 33.5 & 39 & 51.3 & 51.9 & 42.1 & 8.6 & $A$ & 125.7 \\
\hline Sunflower seeds & 10.6 & 8.5 & 9.3 & 11 & 10.5 & 12.8 & 4.3 & $\Lambda$ & 150.6 \\
\hline Soybeans, thousand tons & 1636 & 2371 & 2716 & 3143 & 3622 & 4027 & 1656 & $\Delta$ & 169.8 \\
\hline Potato & 30.2 & 24.3 & 25.4 & 22.5 & 21.7 & 22.4 & -1.9 & $\nabla$ & 92.2 \\
\hline Vegetables & 14.7 & 12.8 & 13.2 & 13.2 & 13.6 & 13.7 & 0.9 & $\Delta$ & 107.0 \\
\hline Food melons & 1.4 & 1.5 & 1.8 & 1.9 & 1.8 & 2 & 0.5 & $\Delta$ & 133.3 \\
\hline $\begin{array}{l}\text { Fruits and berries, thousand } \\
\text { tons }\end{array}$ & 2942 & 2780 & 2676 & 3056 & 2683 & 3337 & 557 & $\Delta$ & 120.0 \\
\hline Grapes, thousand tons & 439 & 570 & 520 & 601 & 580 & 628 & 58 & $\Delta$ & 110.2 \\
\hline \multicolumn{10}{|c|}{ Livestock products, million tons } \\
\hline $\begin{array}{l}\text { Livestock and poultry for } \\
\text { slaughter in slaughter } \\
\text { weight, thousand tons: } \\
\text { cattle }\end{array}$ & 1633 & 1621 & 1617 & 1589 & 1569 & 1608 & -13 & $\nabla$ & 99.2 \\
\hline Pigs & 2816 & 2964 & 3083 & 3355 & 3516 & 3744 & 780 & $\mathbf{A}$ & 126.3 \\
\hline Sheep and goats & 190 & 203 & 204 & 213 & 219 & 224 & 21 & $\overline{1}$ & 110.3 \\
\hline Poultry & 3831 & 4164 & 4541 & 4622 & 4941 & 4980 & 816 & $\Delta$ & 119.6 \\
\hline Milk & 30.5 & 30 & 29.9 & 29.8 & 30.2 & 30.6 & 0,6 & $\Delta$ & 102.0 \\
\hline Eggs, billion pcs. & 41.3 & 41.7 & 42.5 & 43.5 & 44.8 & 44.9 & 3.2 & $\Delta$ & 107.7 \\
\hline Honey, thousand tons & 68 & 74 & 67 & 69 & 65 & 65 & -9 & $\nabla$ & 87.8 \\
\hline
\end{tabular}

* Compiled by the author on the basis of the Agriculture in Russia, (2019) http://gks.ru/bgd/regl/bl9_38/ 


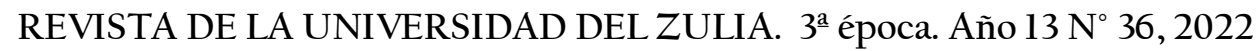
Golovin Artem Alekseevich et al. /// Results of the Russian State policy in the field of increasing ... 93-113 DOI: http://dx.doi.org/10.46925//rdluz.36.07

Table 2 - Assessment of the impact of the extensive factor on the production of food products and raw materials for its production in Russia for 2013-2018.

\begin{tabular}{|c|c|c|c|c|c|c|c|c|c|}
\hline Culture & $\stackrel{n}{\tilde{n}}$ & $\stackrel{+}{\stackrel{\overbrace{}}{\sigma}}$ & $\frac{n}{\grave{n}}$ & 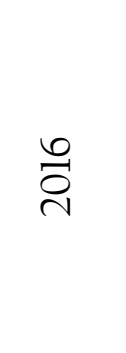 & $\stackrel{へ}{\circ}$ & $\stackrel{\infty}{\stackrel{0}{\sigma}}$ & 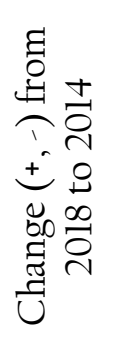 & 营 & 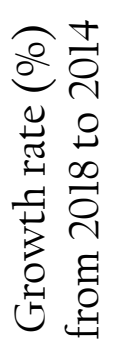 \\
\hline \multicolumn{10}{|c|}{ Cultivated area / area of perennial plantations, thousand hectares } \\
\hline Winter wheat & 12334 & 12155 & 13364 & 14041 & 14954 & 15296 & 3141 & $\mathbf{A}$ & 125.8 \\
\hline Spring wheat & 12729 & 13103 & 13463 & 13668 & 12969 & 11968 & -1135 & $\nabla$ & 91.3 \\
\hline Rye (winter) & 1831 & 1876 & 1291 & 1262 & 1180 & 978 & -898 & $\nabla$ & 52.1 \\
\hline Corn for grain & 2450 & 2677 & 2762 & 2887 & 3019 & 2452 & -225 & $\nabla$ & 91.6 \\
\hline Triticale & 240 & 237 & 235 & 212 & 160 & 138 & -99 & $\nabla$ & 58.2 \\
\hline Winter barley & 392 & 584 & 521 & 560 & 522 & 480 & -104 & $\nabla$ & 82.2 \\
\hline Spring barley & 8628 & 8771 & 8344 & 7762 & 7488 & 7845 & -926 & $\nabla$ & 89.4 \\
\hline Oats & 3324 & 3258 & 3047 & 2860 & 2887 & 2853 & -405 & $\nabla$ & 87.6 \\
\hline Millet & 470 & 506 & 595 & 435 & 265 & 260 & -246 & $\nabla$ & 51.4 \\
\hline Buckwheat & 1096 & 1008 & 957 & 1205 & 1692 & 1045 & 37 & $\Delta$ & 103.7 \\
\hline Rice & 190 & 197 & 202 & 208 & 187 & 182 & -15 & $\nabla$ & 92.4 \\
\hline Legumes & 1979 & 1595 & 1587 & 1752 & 2221 & 2754 & 1159 & $\Delta$ & 172.7 \\
\hline Sugar beet & 904 & 917 & 1021 & 1107 & 1198 & 1127 & 210 & $A$ & 122.9 \\
\hline Sunflower & 7271 & 6911 & 7013 & 7607 & 7994 & 8160 & 1249 & $A$ & 118.1 \\
\hline Soy & 1532 & 2012 & 2131 & 2237 & 2636 & 2949 & 937 & $\Delta$ & 146.6 \\
\hline Potato & 2138 & 1599 & 1562 & 1441 & 1350 & 1325 & -274 & $\nabla$ & 82.9 \\
\hline Vegetables & 671 & 563 & 563 & 551 & 535 & 526 & -37 & $\nabla$ & 93.4 \\
\hline Food melons & 154 & 157 & 181 & 170 & 152 & 140 & -17 & $\nabla$ & 89.2 \\
\hline $\begin{array}{l}\text { Fruit and berry } \\
\text { plantations }\end{array}$ & 502 & 472 & 467 & 460 & 462 & 466 & -6 & $\nabla$ & 98.7 \\
\hline Vine plantations & 62 & 90 & 89 & 91 & 91 & 94 & 4 & $\Delta$ & 104.4 \\
\hline \multicolumn{10}{|c|}{ Livestock inventory, thousand heads of cattle } \\
\hline $\begin{array}{l}\text { Cattle (without } \\
\text { cows) }\end{array}$ & 10903 & 10657 & 10506 & 10380 & 10343 & 10209 & -448 & $\nabla$ & 95.8 \\
\hline Cows & 8661 & 8263 & 8115 & 7966 & 7951 & 7943 & -320 & $\nabla$ & 96.1 \\
\hline Sheep and goats & 24337 & 24445 & 24606 & 24717 & 24389 & 23129 & -1316 & $\nabla$ & 94.6 \\
\hline Bird, million heads & 495 & 524 & 544 & 550 & 556 & 541 & 17 & $\Delta$ & 103.2 \\
\hline Bee colonies & 3341 & 3446 & 3425 & 3317 & 3182 & 3094 & -352 & $\nabla$ & 89.8 \\
\hline
\end{tabular}

* Compiled by the author on the basis of the Agriculture in Russia, (2019) http://gks.ru/bgd/regl/bl9_38/

The data in Table 2 confirm that one of the growth factors in the production of wheat, buckwheat and legumes was the increase in the cultivated area, i.e., the extensive factor, and 
REVISTA DE LA UNIVERSIDAD DEL ZULIA. $3^{a}$ época. Año $13 \mathrm{~N}^{\circ}$ 36, 2022

Golovin Artem Alekseevich et al. /// Results of the Russian State policy in the field of increasing ... 93-113

DOI: http://dx.doi.org/10.46925//rdluz.36.07

for corn, it is safe to say that the growth in production was provided by the intensive factor. The production of industrial crops increased primarily due to an increase in the cultivated area. With regard to potatoes, vegetables, and food melons, we can say that the impact of the extensive factor on the production volume is quite strong. Perennial plantations showed a decrease in area, with the exception of an increase of 4 thousand hectares of vineyards.

The production of livestock products showed dependence on the extensive factor only for poultry, the number of which has increased, for cattle and honey, the reduction in production of which was accompanied by a reduction in the number of livestock and number of bee colonies.

Thus, the impact of the extensive factor is most fully traced in cereals and leguminous crops, with the exception of corn and industrial crops. For livestock products, the impact of the extensive factor is most strongly traced in cattle and poultry meat, as well as in honey.

The result of efforts to increase the efficiency of agricultural producers is the yield of agricultural crops and the productivity of animals. These indicators show the final impact of intensive factors (Figure 3).

The values presented in Table 3 indicate that Russian agricultural producers actively invest in improving production efficiency.

There is a tendency of yield growth in almost all agricultural crops. The largest increase in yield was shown by sunflower (22.1\%), and the smallest by winter wheat $(0.3 \%)$. This situation is a consequence of the achieved maximum possible level of yield under existing conditions. At the same time, the relatively high rate of sunflower yield growth is caused by the relative novelty of the crop, in contrast to the rest, which are traditional. Organizations have not yet fully worked out the cultivation technology, they continue to experiment with varieties, select the most suitable for specific conditions. The yield's decrease in 2018 compared to 2014 was shown by spring barley, millet, and leguminous crops. This decrease, as well as the change in the yield of other agricultural crops, should be attributed to volatility under the influence of natural and climatic conditions. As noted above, the existing yield is a probable maximum under the current climatic conditions, forms, and conditions of production organization. Volatility at the level of 10, possibly more, will take place under the influence of weather conditions and beyond. 


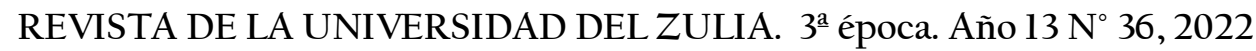

Golovin Artem Alekseevich et al. /// Results of the Russian State policy in the field of increasing ... 93-113

DOI: http://dx.doi.org/10.46925//rdluz.36.07

Table 3 - Assessment of the impact of intensive factors on the production of food products and raw materials for its production in Russia for 2013-2018.

\begin{tabular}{|c|c|c|c|c|c|c|c|c|c|}
\hline Culture & 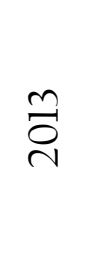 & 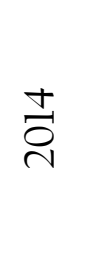 & $\stackrel{i n}{\stackrel{\overbrace{}}{~}}$ & $\begin{array}{l}\stackrel{0}{\circ} \\
\stackrel{\overbrace{}}{\sim}\end{array}$ & 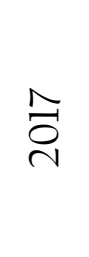 & $\frac{\infty}{\stackrel{\infty}{\sim}}$ & 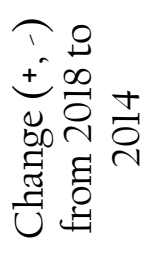 & 莺 & 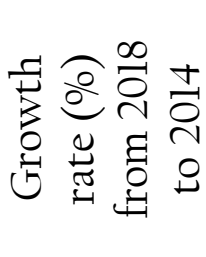 \\
\hline \multicolumn{10}{|c|}{ Productivity, c/ ha } \\
\hline Winter wheat & 29.9 & 35.1 & 32 & 37.6 & 41.7 & 35.2 & 0.1 & $\Delta$ & 100.3 \\
\hline Spring wheat & 14.2 & 14.7 & 15.5 & 15.7 & 18.9 & 16.8 & 2.1 & $\Delta$ & 114.3 \\
\hline Rye (winter) & 18.9 & 17.7 & 16.7 & 20.3 & 21.7 & 20.1 & 2.4 & $\Delta$ & 113.6 \\
\hline Corn for grain & 50.1 & 43.6 & 49.3 & 55.1 & 49 & 48.1 & 4.5 & $\Delta$ & 110.3 \\
\hline Triticale & 24.1 & 26.4 & 23.1 & 27.8 & 29.1 & 27 & 0.6 & $\Delta$ & 102.3 \\
\hline Winter barley & 40.3 & 35.9 & 40 & 39.5 & 41.9 & 38.8 & 2.9 & $\Delta$ & 108.1 \\
\hline Spring barley & 18.1 & 21.8 & 20 & 20.8 & 25.2 & 20.5 & -1.3 & $\nabla$ & 94.0 \\
\hline Oats & 16.4 & 17.1 & 16 & 17.3 & 19.6 & 17.3 & 0.2 & $\Delta$ & 101.2 \\
\hline Millet & 11.8 & 12.3 & 12.9 & 15.4 & 13.4 & 11.6 & -0.7 & $\nabla$ & 94.3 \\
\hline Buckwheat & 9.2 & 9.3 & 9.5 & 10.6 & 10.2 & 9.5 & 0.2 & $\Delta$ & 102.2 \\
\hline Rice & 49.5 & 53.6 & 55.8 & 53 & 53.1 & 57.6 & 4 & $\Delta$ & 107.5 \\
\hline Legumes & 12.1 & 14.6 & 15.9 & 17.5 & 20.1 & 13 & -1.6 & $\nabla$ & 89.0 \\
\hline Sugar beet & 442 & 370 & 388 & 470 & 442 & 381 & 11 & $\Delta$ & 103.0 \\
\hline Sunflower & 15.5 & 13.1 & 14.2 & 15.1 & 14.5 & 16 & 2.9 & $\Delta$ & 122.1 \\
\hline Soy & 13.6 & 12.3 & 13 & 14.8 & 14.1 & 14.7 & 2.4 & $\Delta$ & 119.5 \\
\hline Potato & 145 & 153 & 164 & 158 & 163 & 170 & 17 & $\Delta$ & 111.1 \\
\hline Vegetables & 214 & 219 & 226 & 229 & 241 & 243 & 24 & $\Delta$ & 111.0 \\
\hline Food melons & 105 & 104 & 109 & 119 & 127 & 147 & 43 & $\Delta$ & 141.3 \\
\hline Fruits and berries & 77.1 & 77.3 & 77.3 & 88.4 & 77.9 & 96 & 18.7 & $\Delta$ & 124.2 \\
\hline Grapes & 93.6 & 78.1 & 77.8 & 86.6 & 84.9 & 91.9 & 13.8 & $\Delta$ & 117.7 \\
\hline \multicolumn{10}{|c|}{ Productivity, $\mathrm{kg}$} \\
\hline $\begin{array}{l}\text { Production of livestock per } \\
\text { head (yield, growth, weight } \\
\text { gain): } \\
\text { Cattle }\end{array}$ & 146 & 149 & 152 & 150 & 154 & 155 & 6 & $\Delta$ & 104.0 \\
\hline Pigs & 191 & 200 & 209 & 203 & 208 & 208 & 8 & 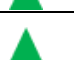 & 104.0 \\
\hline Milk per cow & $\begin{array}{r}389 \\
3 \\
\end{array}$ & $\begin{array}{r}402 \\
1 \\
\end{array}$ & $\begin{array}{r}413 \\
4 \\
\end{array}$ & $\begin{array}{r}421 \\
8 \\
\end{array}$ & $\begin{array}{r}436 \\
8 \\
\end{array}$ & 4492 & 471 & $\Delta$ & 111.7 \\
\hline $\begin{array}{l}\text { Average annual egg } \\
\text { production of laying hens, } \\
\text { pcs. }\end{array}$ & 305 & 308 & 310 & 308 & 311 & 305 & -3 & $\nabla$ & 99.0 \\
\hline Honey & 20 & 21 & 20 & 21 & 20 & 21 & 0 & $\nabla$ & 97.8 \\
\hline
\end{tabular}

* Compiled by the author on the basis of the Agriculture in Russia, (2019) http://gks.ru/bgd/regl/bl9_38/ 
REVISTA DE LA UNIVERSIDAD DEL ZULIA. $3^{a}$ época. Año $13 \mathrm{~N}^{\circ}$ 36, 2022

Golovin Artem Alekseevich et al. /// Results of the Russian State policy in the field of increasing ... 93-113

DOI: http://dx.doi.org/10.46925//rdluz.36.07

On the positive side, it is necessary to assess the level of development of animal husbandry, the productivity of which grows both in meat and milk. The dynamics of productivity decline was shown by poultry farming focused on egg production, as well as beekeeping. The decrease in egg production is insignificant and, in general, may correspond to the level of 2013. The situation with beekeeping is ambiguous, since the statistics considered all bee colonies, even those who suffered and did not recover from poisoning with plant protection products. In addition, beekeeping in Russia is the production of the population, i.e., it is difficult to talk about the results of investments in breeding work, modernization of production forms and production technologies.

Thus, we can conclude that agriculture in Russia develops predominantly in an intensive way, which is a positive factor. However, agricultural producers, together with the state, need to determine development directions that take into account the minimization of the impact of weather conditions. In animal husbandry, it is advisable for the state to direct additional resources to the development of the industry since the existing growth rates are insufficient to achieve full self-sufficiency of the country in animal products in the near future.

Having determined the nature of the development of agricultural production, let us consider the average producer prices, as an element that forms the level of food availability for the country's population (Table 4).

Analysis of changes in food sales prices showed an increase in all products of plant and animal origin, with the exception of buckwheat, potatoes, food melons. Buckwheat is characterized as a highly volatile crop. High variability is shown by the yield, and, consequently, volume of production and selling price. The decrease of prices for potatoes and food melons does not exceed 3\%, which is insignificant considering the study period. Among other agricultural crops, millet, sunflower seeds, fruits, and berries, as well as grapes showed the highest sales price increases (Golovin, 2020c).

Considering the prices for livestock products, the largest price increase is for cattle meat, for 2014-2018 and amounted to 33.8\%, as well as to sheep and goats (26.5\%). Prices for poultry meat, milk, chicken eggs and honey showed increase of $10 \%$. The lowest growth rates were shown by pork in 2014-2018 as it increased in price by only 5.8\%. 
REVISTA DE LA UNIVERSIDAD DEL ZULIA. $3^{a}$ época. Año $13 \mathrm{~N}^{\circ}$ 36, 2022

Golovin Artem Alekseevich et al. /// Results of the Russian State policy in the field of increasing ... 93-113

DOI: http://dx.doi.org/10.46925//rdluz.36.07

In general, the increase in prices for food products and raw materials for their production does not contribute to the increase in the food availability, however, it provides a payback for agricultural producers, which means it ensures the economic security of the country and the industry.

Table 4 - Average prices of agricultural producers in Russia for 2013-2018.

\begin{tabular}{|c|c|c|c|c|c|c|c|c|c|}
\hline Culture & $\ddot{\tilde{\imath}}$ & 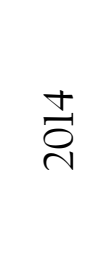 & 吕 & $\stackrel{0}{\circ}$ & 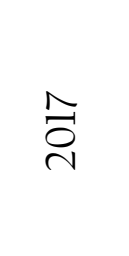 & $\stackrel{\infty}{\stackrel{2}{\sim}}$ & 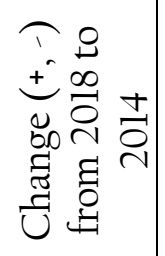 & 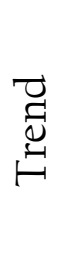 & 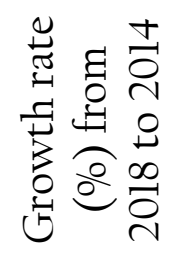 \\
\hline \multicolumn{10}{|c|}{ Crop production, thousand rubles / $t$} \\
\hline Wheat & 6.7 & 6.8 & 8.8 & 8.8 & 7.3 & 8.5 & 1.7 & $\mathbf{A}$ & 124.6 \\
\hline Rye (winter) & 4.9 & 4.7 & 5.2 & 6.1 & 5.6 & 5.6 & 2.1 & $\bar{A}$ & 136.4 \\
\hline Corn for grain & 6.6 & 5.8 & 7.9 & 8.3 & 7.0 & 7.9 & 2.1 & 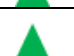 & 120.2 \\
\hline Barley & 6.4 & 5.5 & 7.3 & 7.7 & 6.8 & 8.1 & 2.6 & 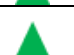 & 147.1 \\
\hline Oats & 5.8 & 5.0 & 5.5 & 6.4 & 6.5 & 6.0 & 1.0 & A & 120.2 \\
\hline Millet & 5.2 & 5.6 & 7.4 & 6.4 & 5.1 & 11.8 & 6.2 & $\Delta$ & 210.1 \\
\hline Buckwheat & 7.2 & 8.4 & 20.1 & 25.9 & 15.7 & 7.5 & -0.9 & $\nabla$ & 89.8 \\
\hline Legumes & 8.4 & 8.5 & 13.1 & 16.7 & 12.3 & 9.5 & 1.1 & $\Delta$ & 112.9 \\
\hline Sugar beet & 32.3 & 45.0 & 52.1 & 48.8 & 36.8 & 46.2 & 1.3 & A & 102.8 \\
\hline Sunflower seeds & 12.0 & 11.5 & 20.3 & 21.9 & 17.0 & 17.8 & 6.2 & $\Delta$ & 154.1 \\
\hline Soy beans & 15.0 & 17.0 & 19.0 & 23.5 & 21.1 & 22.6 & 5.6 & $A$ & 133.1 \\
\hline Potato & 9.4 & 12.9 & 13.2 & 10.2 & 11.6 & 12.5 & -0.3 & $\nabla$ & 97.3 \\
\hline Vegetables & 31.5 & 36.3 & 45.5 & 45.2 & 47.0 & 45.1 & 8.8 & $\Delta$ & 124.1 \\
\hline Food melons & 2.9 & 8.5 & 5.8 & 5.3 & 6.4 & 8.4 & -0.1 & $\nabla$ & 98.8 \\
\hline Fruits and berries & 26.5 & 27.1 & 44.2 & 47.3 & 45.6 & 39.5 & 12.4 & $\Delta$ & 145.5 \\
\hline Grapes & 16.5 & 16.8 & 22.0 & 24.7 & 29.9 & 29.9 & 13.1 & $\Delta$ & 178.0 \\
\hline \multicolumn{10}{|c|}{ Livestock products, thousand rubles / $t$} \\
\hline $\begin{array}{l}\text { Livestock and poultry } \\
\text { (live weight): cattle }\end{array}$ & 72.1 & 74.4 & 93.3 & 96.6 & 97.6 & 99.5 & 25.1 & $\Delta$ & 133.8 \\
\hline Pigs & 71.7 & 94.1 & 103.0 & 94.0 & 96.5 & 99.6 & 5.5 & 1 & 105.8 \\
\hline Sheep and goats & 74.3 & 71.0 & 79.7 & 85.8 & 89.4 & 89.8 & 18.8 & 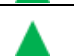 & 126.5 \\
\hline Live poultry & 54.4 & 63.7 & 71.3 & 72.3 & 68.1 & 70.8 & 7.2 & 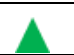 & 111.3 \\
\hline Raw milk & 15.9 & 19.6 & 20.6 & 21.8 & 24.5 & 22.9 & 3.2 & 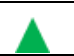 & 116.5 \\
\hline $\begin{array}{l}\text { Fresh chicken eggs in } \\
\text { shell, } 1000 \text { pcs. }\end{array}$ & 3.2 & 3.4 & 4.2 & 4.2 & 3.6 & 3.9 & 0.5 & $\mathbf{A}$ & 114.4 \\
\hline Honey & 404.7 & 415.9 & 442.2 & 462.3 & 468.2 & 454.7 & 38.7 & $\Delta$ & 109.3 \\
\hline
\end{tabular}

* Compiled by the author on the basis of the Agriculture in Russia, (2019) http://gks.ru/bgd/regl/bl9_38/ 
REVISTA DE LA UNIVERSIDAD DEL ZULIA. $3^{a}$ época. Año $13 \mathrm{~N}^{\circ}$ 36, 2022

Golovin Artem Alekseevich et al. /// Results of the Russian State policy in the field of increasing ... 93-113

DOI: http://dx.doi.org/10.46925//rdluz.36.07

In conclusion of the study, let us assess the consumption of basic food products by the population of Russia (Table 5).

Table 5 - Assessment of consumption of basic food products by the population of Russia for 2013-2018.

\begin{tabular}{|c|c|c|c|c|c|c|c|c|c|}
\hline Culture & $\stackrel{\tilde{c}}{\stackrel{\lambda}{1}}$ & 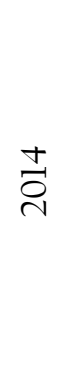 & $\stackrel{n}{\stackrel{n}{\imath}}$ & $\begin{array}{l}\stackrel{0}{0} \\
\stackrel{\sim}{\sim}\end{array}$ & 气ે & $\stackrel{\infty}{\stackrel{\overbrace{}}{\sigma}}$ & 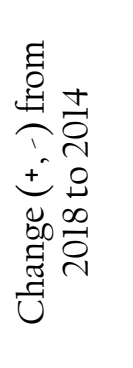 & 苞 & 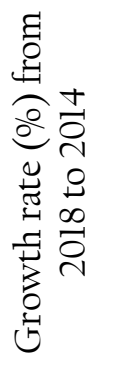 \\
\hline \multicolumn{10}{|c|}{ Food products of plant origin, $\mathrm{kg} /$ person / year } \\
\hline Consumption of bread products & 118 & 118 & 118 & 117 & 117 & 116 & -2 & $\nabla$ & 98.3 \\
\hline Potato consumption & 94 & 93 & 91 & 90 & 90 & 89 & -4 & $\nabla$ & 95.7 \\
\hline $\begin{array}{l}\text { Consumption of vegetables and } \\
\text { food crops }\end{array}$ & 102 & 102 & 102 & 102 & 104 & 107 & 5 & $\Delta$ & 104.9 \\
\hline Consumption of fruits and berries & 63 & 63 & 60 & 60 & 59 & 61 & -2 & $\nabla$ & 96.8 \\
\hline Sugar consumption & 40 & 40 & 39 & 39 & 39 & 39 & -1 & $\nabla$ & 97.5 \\
\hline Vegetable oil consumption & 13.7 & 13.8 & 13.6 & 13.7 & 13.9 & 14.0 & 0 & $\Delta$ & 101.4 \\
\hline \multicolumn{10}{|c|}{ Food products of animal origin, $\mathrm{kg} /$ person / year } \\
\hline $\begin{array}{l}\text { Consumption of meat and meat } \\
\text { products }\end{array}$ & 75 & 74 & 73 & 74 & 75 & 75 & 1 & $\Delta$ & 101.4 \\
\hline $\begin{array}{l}\text { Consumption of milk and dairy } \\
\text { products }\end{array}$ & 245 & 239 & 233 & 231 & 230 & 229 & -10 & $\nabla$ & 95.8 \\
\hline $\begin{array}{l}\text { Consumption of eggs and egg } \\
\text { products, pcs. }\end{array}$ & 271 & 271 & 273 & 277 & 282 & 284 & 13 & $\Delta$ & 104.8 \\
\hline $\begin{array}{l}\text { Consumption of fish and fish } \\
\text { products in live weight (raw } \\
\text { weight) }\end{array}$ & 27.3 & 25.7 & 22.3 & 22.3 & 22.9 & 20.2 & -6 & $\nabla$ & 78.6 \\
\hline
\end{tabular}

* Compiled by the author on the basis of the Agriculture in Russia, (2019) http://gks.ru/bgd/regl/bl9_38/ and Consumption of basic food products by the population - 2020, https://rosstat.gov.ru/storage/mediabank/vqBMi2zc/Potr20.rar

Table 5 shows that the consumption of bread products, potatoes, sugar, fruits, and berries decrease. According to nutritionists, the decrease in the consumption of potatoes, bread products and sugar can be attributed to a positive trend, while the decrease in the consumption of fruits and berries can be assessed from the negative side. The consumption of vegetable oil, vegetables and food crops shows a similar ambiguous dynamic. Nutritionists agree that the consumption of vegetable oil should be reduced, but in our case, it increases. The increase in consumption of vegetables and food melons and gourds can be unambiguously assessed on the positive side (Golovin et al., 2020d). 
REVISTA DE LA UNIVERSIDAD DEL ZULIA. $3^{a}$ época. Año $13 \mathrm{~N}^{\circ}$ 36, 2022

Golovin Artem Alekseevich et al. /// Results of the Russian State policy in the field of increasing ... 93-113

DOI: http://dx.doi.org/10.46925//rdluz.36.07

The consumption of animal products increases for meat, meat products, eggs and egg products and decreases for milk, dairy products, fish, and fish products. These dynamic changes are ambiguous. Thus, a decrease in the consumption of dairy and fish products is a negative trend. At the same time, nutritionists talk about the need to limit the consumption of eggs and egg products, but in our case, their consumption only increases. The relative availability and cheapness of eggs are likely to determine the growth in their consumption. At the same time, the increase in meat consumption is not due to cattle meat, but due to the meat of pigs. There is a significant imbalance in consumption, with pig meat forming the basis of the population's diet, which is negatively assessed by nutritionists (Golovin, 2020 b).

\section{Discussions}

The results obtained make it necessary to determine the state's activity in supporting agriculture as quite effective, but there are several problematic points. So, despite the growth in production volumes, there is a lag in vegetable growing, fruit growing, cattle breeding, as well as milk production. These areas of agriculture form a healthy diet of the population, but at present they are not able to cover the scientifically substantiated needs of the population in these products. Instead, highly profitable, including export-oriented, areas actively develop - grain farming and pig breeding (Golovin et al., 2020a). These areas are important, and not only for obtaining export earnings, but shift of focus towards maximizing income can cause irreparable harm to both food security and land resources.

Any state industry support is aimed at developing industry or specific direction of production to the level where it can maintain its work at the level sufficient for the ongoing development. Such industries were the cultivation of wheat, sugar beets, sunflowers, as well as pig breeding. The feasibility of reducing state support for these areas will free up significant financial resources, which it is advisable to direct into livestock breeding, including dairy, vegetable growing, fruit growing, viticulture. An increase in state support for these areas will increase production, and employment in rural areas, reduce imports and open up new opportunities for the export of goods with high added value. Strengthening government support will help curb the rise in prices for healthy foods included in the set of "proper" nutrition.

The redistribution of state support will create the risk of an increase in prices for bread and pork, but there is some advantage in this. Nutritionists recommend reducing the 
REVISTA DE LA UNIVERSIDAD DEL ZULIA. $3^{a}$ época. Año $13 \mathrm{~N}^{\circ}$ 36, 2022

Golovin Artem Alekseevich et al. /// Results of the Russian State policy in the field of increasing ... 93-113

DOI: http://dx.doi.org/10.46925//rdluz.36.07

consumption of these foods, which will happen when their prices rise, and they will be replaced by other, healthier foods. However, it is unreasonable to completely deprive grain industry of state support, it is necessary to preserve it in relation to the high-quality grain produced, the development of breeding and seed production, as well as during the implementation of projects to improve the production and logistics infrastructure (Zyukin et al., 2020a). In Russia, the production of wheat of 3 and 4 grades prevails with 5 existing ones, where 1 is the highest. It is necessary to switch to subsidizing the production of grain only $l$ and 2 grades and leave the rest of the production without subsidies. The growth in the grain production of 1 and 2 grades will significantly increase the size of export earnings, since the price of wheat of the 1 grade is twice more than 5 of the fifth grade (Zyukin et al., 2020b).

Thus, the need to shift the focus towards supporting the production of vegetables and fruit and berry crops, as well as dairy and beef cattle breeding will help increase the production of food with high added value, curb the rise in prices for these products, form healthier diet of the population, and ensure the availability food. At the same time, shift of focus for supporting the production of grades 1 and 2 will increase export earnings, and the quality of grain products in the country will increase. In pig breeding, the shift of state support from growing to processing will also increase the export of products with high added value.

\section{Conclusions}

In the course of the study, the following conclusions were made:

1. The total volume of food production in Russia increases. During the study period, the production of cereals and legumes increased, with the exception of crops such as rye, triticale, barley, oats, millet, and rice. The production volumes of industrial and fruit crops show rather high growth rates. Among vegetable and food melons, only potatoes showed dynamics of production decrease. Production of cattle meat and honey decreased. The rest of the categories of meat, as well as milk and eggs showed an increase in production.

2. Assessment of the impact of the extensive factor on the volume of food production showed that the strongest impact is traced in relation to all cereals, with the exception of corn. The growth in the production of industrial crops also maintains, including due to the extensive factor. Vegetables and melons showed an increase in production volumes with a 
REVISTA DE LA UNIVERSIDAD DEL ZULIA. $3^{a}$ época. Año $13 \mathrm{~N}^{\circ}$ 36, 2022

Golovin Artem Alekseevich et al. /// Results of the Russian State policy in the field of increasing ... 93-113

DOI: http://dx.doi.org/10.46925//rdluz.36.07

decreasing area under crops. The decrease in the production of cattle meat and honey due to the extensive factor.

3. The analysis of crop yields makes it possible to evaluate the efforts of agricultural producers as effective. This estimate is determined by the growing yield of almost all crops, with the exception of spring barley, millet, and legumes. Intensification of livestock production provides an increase in productivity for meat products and milk, and on the contrary, a decrease in eggs and honey. However, even the existing growth rates are insufficient to ensure high profitability of production, and, consequently, for sustainable incoming development.

4. Analysis of the average selling prices of agricultural products by commodity producers indicates a widespread growth, which leads to a decrease in the availability of food. Among the products of plant origin, only buckwheat, potatoes and food melons showed a decrease. There is a decrease in the price of buckwheat and greater return to the current price after a shortage of the product and corresponding increase in prices in 2015-2017. The decrease in prices for potatoes and food melons is more of temporary market changes.

5. Assessment of food consumption has revealed a number of ambiguous trends. Thus, the reduction in the consumption of bread products, potatoes, sugar can be attributed to the positive trend. The increase in consumption of vegetable oil, eggs, and egg products, as well as a decrease in the consumption of dairy and fish products, fruits, and berries, according to doctors, is a negative trend. The situation with an increase in the consumption of vegetables and food melons is undoubtedly positive. The increase in meat consumption is generally positive, but the shift of focus to pork and low consumption of beef and poultry also have a negative impact on public health.

Acknowledgments and Funding

The study was carried out within the framework of the project for the implementation of an intra-university grant under the Southwestern State University Development Program (PRIORITY-2030) No. PR2030 / 2021-58.

\section{References}

Agriculture in Russia, (2019) Retrieved from: http://gks.ru/bgd/regl/bl9_38/ 
REVISTA DE LA UNIVERSIDAD DEL ZULIA. $3^{a}$ época. Año $13 \mathrm{~N}^{\circ}$ 36, 2022

Golovin Artem Alekseevich et al. /// Results of the Russian State policy in the field of increasing ... 93-113 DOI: http://dx.doi.org/10.46925//rdluz.36.07

Altukhov, A.I. (2019). Food security paradigm in Russia (Moscow, Fund "Personnel reserve"), 685 p.

Beluhova-Uzunova, R., Hristov, K. and Shishkova, M. (2020) The common agricultural policy post 2020 - farmers' perception and policy implication. Scientific papers-series management economic engineering in agriculture and rural development, 20 (2), 61-68.

Brown, C.G. (1994) Removing redundant regulation in the reform of agricultural policies the case of the common agricultural policy of the EC. Food policy, 19 (6), 550-556, DOI10.1016/0306-9192(94)90045-0

Calegari, E., Fabrizi, E. Guastella, G. and Timpano, F. (2021). EU regional convergence in the agricultural sector: Are there synergies between agricultural and regional policies? Papers in regional science, 100 (1), DOI: 10.1111/pirs.12569

Consumption of basic food products by the population - 2020, Retrieved from: https://rosstat.gov.ru/storage/mediabank/vqBMi2zc/Potr20.rar

Drokin, V.V. and Zhuravlev, A.S. (2020). On the food security of the rural population of the regions of Russia. Regional economics and management: electronic scientific journal, 2 (62), 21.

Ecker, O. and Hatzenbuehler, P.L. (2021). Food consumption-production response to agricultural policy and macroeconomic change in Nigeria. Applied economic perspectives and policy, DOI10.1002/aepp.13161

Golovin, A., Derkach, N. and Zyukin, D. (2020a). Development of food exports to ensure economic security. Economic Annals-XXI, 186(11-12), 75-85, DOI10.21003/ea.V186-09

Golovin, A.A. (2020b). Consumption of basic food products for assessing the country's food security. Region: systems, economics, management, 2 (49), 84-89.

Golovin, A.A. (2020c). The cost components of the consumption of basic food products for assessing the country's food security. Economy and entrepreneurship, 5 (118), 270-273.

Golovin, A.A., Golovin, A.A., Dobrinova, T.V., Parkhomchuk, M.A. and Chebotareva, K.A. (2020d). Research on the consumption of basic food products by the Russian population in the context of food security. Proceedings of the 35th International Business Information Management Association Conference, Spain Seville, 12192-12202

Guo, X.D., Lung, P. Sui, J.L., Zhang, R.P. and Wang, C. (2021). Agricultural support policies and China's cyclical evolutionary path of agricultural economic growth. Sustainability, 13 (11), 6134, DOI10.3390/sul3116134

Johnson, S.R. (1994). How nutrition policy affects food and agricultural policy. Journal of nutrition, 124 (9), S1871-S1877, DOI10.1093/jn/124.suppl_9.1871S

Pannell, D.J. and Claassen, R. (2020). The Roles of Adoption and Behavior Change in Agricultural Policy. Applied economic perspectives and policy, 42 (1), 31-34, DOI:10.1002/aepp.13009 
REVISTA DE LA UNIVERSIDAD DEL ZULIA. $3^{a}$ época. Año $13 \mathrm{~N}^{\circ}$ 36, 2022

Golovin Artem Alekseevich et al. /// Results of the Russian State policy in the field of increasing ... 93-113

DOI: http://dx.doi.org/10.46925//rdluz.36.07

Razuvaeva, E.B. (2020). Food security as an important component of ensuring the country's economic security. Financial markets and banks, 6, 114-117.

Rodnina, N.V. (2021). Food Security Doctrine: Regional Aspect (Yakutsk: Publishing house YARO RGO "Academy"), 106 p.

Vik, J. (2020). The agricultural policy trilemma: On the wicked nature of agricultural policy making. Land use policy, 99, 105059, DOI10.1016/j.landusepol.2020.105059

Voronin, B.A., Chupina I.P. and Voronina Ya. V. (2020). Conditions for the development of the organic products market in Russia as a factor of food safety compliance. Agrarianeducation and science, $2,6$.

Zyukin, D., Svyatova, O., Zolotareva, E., Bystritskaya, A. and Alyokhina, A. (2020a). The improvement of the model to develop the infrastructure of the grain product subcomplex as the essential attribute to increase the efficiency and ramp up of Russian grain export. Amazonia Investiga, 9(25), 461-470.

Zyukin, D.A., Golovin, A.A., Pronskaya, O.N., Svyatova, O.V., Pshenichnikova, O.V. and Petrushina, O.V. (2020b). Directions and prospects for expanding the export of Russian wheat. Revista de la Universidad del Zulia, 12 (32), 87-101, DOI: https://doi.org/10.46925//rdluz.32.07 